\title{
FROM WARM CHILDHOOD TO COLD CLIMATES: THE YOUNG LIFE OF A CLIMATE CHANGE REFUGEE
}

\author{
Daniel Briggs \\ Social Researcher, Universidad European, Madrid, Spain \\ Email: daniel.briggs@universidadeuropea.es
}

DOI: 10.46587/JGR.2021.v07i02.019

All Noor could remember was that it was getting warmer and the way of life for him and his family was getting more challenging in rural Syria. His earliest memories were taking the cattle out to be herded in the countryside and learning from his father the skills and techniques which, as he thought, would be what he would one day assume. "We knew nothing else as farmers, the people there, they were happy and content working the land" he said. Yet "the days became long and hot" he said to me as he offered me a home-made biscuit. At the time, he said many farmers like his father became destitute and angry as they watched their agricultural businesses fold. The 2006 drought caused major agricultural failures and livestock mortality across the north west of Syria and Noor remembers there being localised protests in which his father participated. At the time, Noor was just six-years old.

No one at the time was attributing this to the possible consequences of manmade climate change. People in rural Syria, however, did notice changes to life when Assad came to power in 2000. People paid more for commodities as inflation increased due to the liberalisation of the economy while domestic policies relating to supporting agriculture were neglected. Surviving in the agricultural industry in particular also became more precarious when Assad scrapped agricultural fuel subsidies which inevitably pushed rural workers into debt. Reflecting on this Noor said "my father became an angry man, sometimes violent, everything he had worked for was disappearing in front of him: he couldn't understand why it was so dry" he recalled.

Science now informs us that this was climate destabilisation - in the main generated from fossil-fuel burning in expansive countries like the U.S., China and India - which resulted in droughts in the Middle East. Notwithstanding, even over the last decade, it is countries like Syria along with others in the eastern Mediterranean belt which have witnessed the worst drought-levels for nine centuries. It is these processes which quickly turned Syria's once-rich soil into the solid-cracked clay it is now, thus yielding the redundant harvests for Noor's family and paving the way for the death of their cattle.

Yet in Syria, non-arable land doesn't stave daily-life survival and pressures to make a living don't desist. Since 2008, food prices increased by average of 26 percent a year across the country. Water (or lack of it) played direct role in deterioration of Syria's domestic economy and this essentially heightened existing tensions which were already historically bound to ethnic and religious division. Persisting droughts and the decrease in precipitation which was the largest observed in the Gulf region at the time which affected more than 1.3 million people prior to the 2011 uprising. Furthermore, during the worst stints of drought in 2006 and 2007, 
85 percent of livestock died and 160 villages were abandoned so rural workers migrated to Syria's cities.

Unsurprisingly perhaps then that hundreds of thousands of farmers lost their livelihoods. Desperate families fled from the countryside to cram themselves into the overspilling cities, each and every one seeking a means to survive. Noor's family were part of this rural exodus and the tipping point for them was in 2009, which marked the third consecutive drought year. With little other choice, Noor and his father's family business finally ran aground and with nothing other than a few belongings, they relocated to the nearest city, Aleppo. He added:

"My family were wheat and vegetable farmers, we found it difficult to survive in the countryside so moved to the nearest city. The crops stopped growing and there was no money in the business."

Noor was just nine years old when his father was negotiating rental prices for an improvised shack in which they could start their lives again in the sprawling suburbs of Aleppo. Yet even in the outskirts, his father was in competition for informal work in the margins. The displacement of hundreds of thousands of other rural migrants meant there was constant vying for even the most basic, low-paid work. He eventually found it as a taxi driver. Approaching adolescence Noor found work in mattresses shop among other small jobs he could pick up as the family didn't have enough money to live on. "There was a tension in the streets always, people always shouting, disagreeing" he recalled as he pours me another tea.

Moreover, the heat did not escape Noor's family or Aleppo's swelling 4.5 million population. The city frequently - and more so perhaps now because of global warming experiences temperatures in excess of 40 degrees centigrade. While weather is generally considered to be a chaotic system, and of course while natural irregularities such as heatwaves have always been a feature of the planet before human evolution, data and science now confirm how persistent droughts and heatwaves can easily be the foundation for social tension to go from simmering to boiling point. In 2013, Hsiang and colleagues published a detailed review of 60 climate-related academic papers which found that extreme weather correlated with the potential for increased violence. It's to say warmer temperatures can result in the greater likelihood of violence.

It is now hypothesised then that these climate pressures and population shifts, along with other urban social pressures such as growing poverty and unemployment, became the catalyst for the 2011 Arab Spring. For example, in 2015, Collin Kelley and his research team published research which concluded that the devastating crop drought between 2007 and 2010 (before the 2011 Arab Spring uprising) was responsible for the desertification of large rural areas in the Fertile Crescent - the vast area which supports the bulk of agriculture in the Middle East. Incoherent and substandard agricultural and environmental policies were also partly to blame when millions of people flooded to the Syrian cities, of which were already suffering inequality and oppressive governance from the Assad regime, making city living conditions across the country even worse and thus being a factor in the subsequent uprising. Noor saw this first hand and watched as his future disappeared:

"It is not a revolution; it is a war. It was inevitable because of the tensions; the Kurds and Arabs hate each other. Some people are rich and more and more in Syria people are poor. This has got worse I mean more and more people are poor, especially us when we were working in the fields as farmers." 
As subsidies reduced, food prices increased and caused discontent - thereafter with the onset of war, food stock was targeted as a way of starving rebel areas where the free army held. While there was little government interest in improving/rescuing agricultural infrastructure, there was also no formal means by which people could make this felt such as through a democratic election since Assad's rule was autocratic and this was partly why rural workers and farmers joined the rebel groups as propaganda was circulated against the Assad regime. This, coupled with a rampant population increase, complex religious and socio-political factors, economic changes related to the increasing prevalence of free-market politics and a wave of political reform which swept the Arab states produced what Noor and millions of other Syrians experienced.

With the advent of war, Syria's economy shrank and the diminished law enforcement ability only laid the platform for illicit business opportunities to exploit the misery. Day-to-day life was intense and insecure. Perhaps quite obviously as a result of war, looting and robbery became commonplace and illicit markets quickly evolved around commodities like food, medicine, petrol, and water. Aleppo was also subject to numerous bombing raids and intense fighting attacks. He remembers how "I mean nothing was safe as Assad army came every day and shooting us and bombing us." Noor and his family tried to weather the war storm for a couple of years but when friends and some close families were killed, his family started to reconsider the limited options available to them. While some of Noor's young friends, only teenagers at the time, had joined the free army others had just disappeared. The choice was fight and risk being killed or wait to potentially be killed anyway. With all their meagre savings, his parents paid for him to be smuggled out of Syria and across the border into Turkey. Noor was just thirteen years old.

Leaving with another friend, they travelled clandestine to Istanbul and, after several days sleeping in the streets, got work in a clothes factory: the $\$ 5$ a day wage was used to pay for their shelter and food. "I had no money, no house, I didn't like the life" he said. He stayed in the job for two years until he realised there was no real future. Noor sits there with his woolly jumper on, outside the snow sits silently as the temperature oscillates around -30 . He leans back and recounts the conversation he had with his ageing and fragile father:

"My parents wouldn't come to me as they are too old to travel. But I said I can't stay in Turkey; it was breaking me. After I told them this, they sold their car and sent me money. I asked someone to help me to go to Europe but I didn't think about where I was going, I had no idea about Norway. I left one year ago (January 2015). Everyone told me to come here, it was best for me. I paid money for a smuggler, in a group in an inflatable boat from Izmir, there was 43 people in there. It took three hours to get to Greece. I came by train, car and lorry sometimes hidden; it took one month from Greece to get to Norway. In my group not everyone went to Norway. Some people came from the same area as me, but many people I didn't know. Each time the group gets smaller as we go through Europe as people go to different countries. They seemed to break up in groups of four and go to different places. Now there are three people who came with me from Greece."

Noor was just 16 when he arrived in Norway. "Wow, here it is so cold, I mean not only the weather, the people as well" he says as he folds his arms somewhat saddened from the general frosty reception which refugees like him get from locals. "They [the local community] think we are terrorists but they don't know what we had to leave and why we came" he adds. Back home, his parents struggle in the government-contested city of Aleppo. He considers it a miracle they are still alive even though contact is intermittent. It is commonplace for the electricity to be periodically cut and there to be episodic access to water on top of the 
continuing everyday risk of being threatened, kidnapped and tortured or killed. He rates their chances of survival limited given that Norway will not repatriate them.

And this is just the beginning of Noor's life in another country, another culture, another social environment and another climate. Indeed, the climate may have been the initial reason for his family's troubles but, at varying points in his life, it has continued to play a role in his pathway and future. As we finish our interview in the wooden hut which is the asylum centre in rural Norway, he clasps my hand and tries to raise a smile, adding "my childhood was warm, before all this mess, now here the climate is cold". And it is cold in more ways than one.

Bio:

Daniel Briggs, Ph.D. is a researcher, writer and inter-disciplinary academic who studies social problems, he has undertaken ethnographic research into social issues from street drug users to terminally-ill patients; from activists to refugees to prostitutes; and from gypsies to gangs and deviant youth behaviours. His book, Dead end lives: Drugs and violence in the city shadows (Policy Press, 2017), won the Division of International Criminology's Outstanding Book Award 2018 (selected by the American Society of Criminology). He has just finished Climate changed: Refugee border stories and the business of misery (Routledge, 2020) and is concluding his first book about the Covid 19 pandemic. 